\title{
Correction to: Beyond the Annual and Aggregate Measurement of Household Inequality: The Case Study of Lake Naivasha Basin, Kenya
}

\author{
Maria Sassi $^{1}$ (D) Gopal Trital $^{1} \cdot$ Poushali Bhattacharjee $^{1}$
}

Published online: 29 March 2021

๑ The Author(s) 2021

\section{Correction to: The European Journal of Development Research https://doi.org/10.1057/s41287-021-00380-6}

During the correction process some typos have been overlooked:

In the section Empirical Strategy, two lines below Eq. 4 in the is misspelled with it.

One line above Eq. 4a, food expenditure is printed as fooexpenditure.

One line above Eq. 4b, there is a missing space before $a t$.

Three lines above Eq. 5, we might is printed as wmight.

Nine lines below Eq. 5, Equation is printed as Eation.

Five lines below Eq. 7, unchanged is printed as unchang.

One line below Eq. 9, As explained is printed as Aexplained.

Six lines below Eq. 9, less is printed as $l s$.

Eight lines below Eq. 9, In our is printed as Iour.

One line above Eq. 11, earnings is printed as enings.

Two lines below Eq. 11, to the is printed as the.

Six lines below Eq. 11, In general is printed as Iral.

The first sub-heading of Results and Discussion, Gini is printed as Gi.

The original article has been corrected.

The original article can be found online at https://doi.org/10.1057/s41287-021-00380-6.

Maria Sassi

maria.sassi@unipv.it

1 Department of Economics and Management, University of Pavia, Via S. Felice 5, 27100 Pavia, Italy 
Open Access This article is licensed under a Creative Commons Attribution 4.0 International License, which permits use, sharing, adaptation, distribution and reproduction in any medium or format, as long as you give appropriate credit to the original author(s) and the source, provide a link to the Creative Commons licence, and indicate if changes were made. The images or other third party material in this article are included in the article's Creative Commons licence, unless indicated otherwise in a credit line to the material. If material is not included in the article's Creative Commons licence and your intended use is not permitted by statutory regulation or exceeds the permitted use, you will need to obtain permission directly from the copyright holder. To view a copy of this licence, visit http://creativecommons.org/licen ses/by/4.0/.

Publisher's Note Springer Nature remains neutral with regard to jurisdictional claims in published maps and institutional affiliations. 